\title{
Political Competition vs. Political \\ Participation: Effects on government's size
}

\author{
Dalibor S. Eterovic \\ Universidad Adolfo Ibañez, School of Government, Diagonal las Torres, Santiago, Chile. \\ Corresponding author. \\ E-mail: dalibor.eterovic@uai.cl.
}

Phone: +56 2198268 .

Nicolás A. Eterovic

Universidad de Chile, Facultad de Economía y negocios, Diagonal Paraguay 257, Santiago, Chile.

E-mail: neterovi@fen.uchile.cl

Phone: +56989924992.

\begin{abstract}
From a theoretical standpoint, there are reasons to believe that political competition and political participation might have opposite effects on the size of government. We investigate empirically this possibility using data from a panel of 104 countries from 1960. We find that reforms enhancing political competition tend to limit the size of government, while reforms increasing political participation tend to increase the size of government. These results are robust for the global sample and across different regions. Controlling for the existence and enforcement of compulsory voting laws does not affect our main results.
\end{abstract}

Our findings reinforce the empirical relevance of the distinction between political competition and participation.

Key words Political competition, political participation, compulsory voting, size of government.

JEL Classification D7; H11. 


\section{Introduction}

Defining democracy is a major task. Yet, an even greater challenge is trying to understand the impact of democracy on economic outcomes. Nevertheless, researchers in economics and political science rave not been discouraged: much research both theoretical and empirical has been done in recent years analyzing the role of political institutions as the drivers of economic development (e.g., Acemoglu and Robinson 2006; Boix 2003; Persson and Tabellini 2003; Dahl 1971).

Democracy comprises a number of complex components. Two of the most noted ingredients in modern day democracy are political participation and political competition. The distinction between political participation and political competition is implicitly or explicitly embodied in many definitions of democracy (e.g., Powell 1982; Przeworski et al. 2000).

In this paper, we build on research done by Aidt and Eterovic (2010) who show that political participation and political competition have different implications on the size of government in 18 Latin American countries. We expand their work in at least two ways. First, we test the hypothesis that political competition and political participation affect government expenditure differently in a much larger world sample, covering more than 100 countries. Second, we show the stability of our findings across regions and econometric specifications. Finally, as in Aidt and Eterovic (2010) we contribute to the existing empirical literature, which isolates the effects of either political competition or participation, by studying the two dimensions jointly.

In our study, we first estimate the impact of political competition and political participation on (central) fiscal expenditure around the world. We then explore how robust are our results by running a battery of tests which include controlling for compulsory voting regimes, including fiscal lags and using instrumental variables technique, specifically a System-GM M estimation.

Our analysis is based on a panel data set with information on fiscal expenditure (for central governments) in 104 countries for the period 1960 to 2000. To measure political competition we use the Polity IV index (Marshall and Jaggers 2007), and to measure political participation we use turnout in elections and referenda (Vanhanen 2000 and 2003a). These variables are available for long periods of time and a broad set of countries which allow us to exploit the often substantial variation in political participation and competition within the countries. In most studies, the Polity IV index is interpreted as a measure of democracy, but, as we shall detail in Section 2, a careful reading of the Polity IV manual suggests that it is more accurate to interpret it as a measure of political competition. Many studies, e.g., Boix (2003, chapter 5), Mulligan et al. (2004), Persson and Tabellini (2006), Kenny and Winer (2006) use a "world" sample that includes as many countries as possible to study the link between fiscal structures and political institutions. The advantage of this approach is that the variation in institutional differences is maximized, but at the same time, countries included in a world sample represent very different economic, geographical, social and cultural experiences. In our estimations we use a large set of control variables to try to control 
for country and region heterogeneity. We also estimate separate regressions for each main geographical areas which are more likely to fulfill the homogeneity conditions to use a panel. However, we acknowledge the importance of peculiar, local specificities in the histories of the countries we study.

The main conclusion we draw from our analysis is that our estimations strongly support the hypothesis that political participation and competition have opposite effects on the size of government. Higher levels of political competition tend to be associated to smaller governments. On the other hand, countries with higher levels of political participation tend to be associated to larger governments. This result is remarkably robust across geographical areas and econometric specifications.

The paper is organized as follows. In Section 2, we introduce the distinction between political competition and participation, deriving testable implications from theoretical literatures and discussing how we obtain operational measures of political competition and participation. We also present our econometric specification. In Section 3, we present our main results, discuss how these add to the current research and run a battery of robustness test. In Section 4, we provide concluding remarks and discuss the issue of causality in detail. Appendix A contains a detailed discussion of data and sources.

\section{Political Competition and Participation: Theory and Measurement ${ }^{1}$}

The idea that democracy has many dimensions is intuitive. In his influential work, Dahl (1971) mentions at least two fundamental dimensions in which democracy is defined. Dahl suggests that political institutions create incentives by fostering or hindering political competition and participation. By political competition we understand the extent to which political power is freely contested by political parties, pressure groups or other organized factions within a defined political structure. Political participation, on the other hand, is related to the rights of individual citizens to participate in the selection of their government through elections and referenda and the extent to which they exercise this right.

\footnotetext{
${ }^{1}$ This section closely follows the theoretical arguments presented in Aidt and Eterovic (2010).

2 Dahl (1971) used the terms "public contestation" and "right to participate," but we prefer to follow Vanhanen (2000) and use the terms "political competition" and "political participation". A third dimension of democracy highlighted by Dahl (1971) is civil liberties.
} 


\subsection{Political Competition}

Two models that help us conceptualize the effect of political competition on policy choices are spatial voting models (Downs 1957; Lindbeck and Weibull 1987) and pressure group models (Becker 1983). In these models, two-party competition produces a strong pull towards the median position in simple Downsian models and can, under some circumstances, lead to Pareto-efficient equilibrium outcomes when voter preferences have a stochastic ideological component (Hettich and Winer 1999, chapter 4; Coughlin and Nitzan 1981). Becker (1983), argues that competition among pressure groups for and against redistribution leads to efficient methods of taxation because political pressure in favor of tax instruments with high deadweight costs is relatively low, while opposition is strong. Using a political agency model, Ferejohn (1986) points to the fact that political competition constraints the ability of politicians to extract rents. Based on these theories we can link political competition to more efficient governments but not necessarily to smaller government. However, there are at least four reasons why we think enhanced political competition is likely to decrease government expenditure.

1. The theory of fiscal illusion: Government revenues are not fully observed by taxpayers. This makes government spending appear less expensive than it is and results in an upwards bias in public spending (Buchanan and Wagner 1977). As pointed out by West and Winer (1980), this effect is, however, mitigated by political competition. In a competitive environment, opposition parties and pressure groups have an incentive to gather information and make it available to voters.

2. Enhanced political competition allows more pressure groups to be catered to in the political calculus (Mueller and Murrel 1986). Subsidy recipients have a comparative advantage in organizing collective action because they, typically, are few in numbers and the benefits bestowed are concentrated (Olson 1965). An increase in political competition is, therefore, often equivalent to empowerment of taxpayers and, as shown in Aidt (2003), for this reason, likely to lead to a reduction in government sponsored redistribution. However, as Olson (1982) points out, when more pressure groups are catered for in the political calculus, the support for particularized spending may increase and the result may be more rather than less spending.

3. Political competition enhances political accountability (e.g., Ferejohn 1986; Persson et al. 1997). When the political power can be contested more freely, challengers provide citizens with alternatives to the incumbent making possible to reduce office rents and other inefficiencies from part of the incumbent's behavior. The outcome of this is likely to be lower taxation.

4. In societies with severe restrictions on political competition (e.g., in a dictatorship) political leaders need to spend substantial public funds on securing and maintaining power (Mulligan et al. 2004). This means that in societies with low political competition, spending levels tend to be high relative to societies with more competitive political institutions. 
From the discussion above we formulate our first hypothesis as:

Hypothesis 1: Political Competition decreases government spending.

\subsection{Political Participation}

We analyze the effect of political participation on the fiscal system using probabilistic voting models (Hettich and Winer 1988 and 1999). In these models, the equilibrium fiscal structure reflects a trade-off between the loss and gain of political support from groups of voters. By lifting property or income restrictions on the right to vote, individuals with lower incomes or less wealth are granted political voice, and the constituency of government is expanded with new voters who are poor relative to the average taxpayer. The Representation Theorem ${ }^{3}$, then, predicts that an extension of the franchise increases the demand for redistribution (Tridimas and Winer 2005). M oreover, political parties are less likely to attach the same weight to groups of voters who normally do not show up to vote as they do to voters with a more predictable turnout pattern. There is substantial evidence from many different countries that richer and better educated citizens are more likely to exercise their right to vote than their poorer and uneducated counterparts. ${ }^{4}$ It is, therefore, reasonable to suppose that an expansion of actual political participation (turnout) also leads to more spending and higher taxation because any increase mostly reflects an increase in participation of poorer and less educated strata of society. All in all, this suggests that an increase in political participation leads to more spending and higher taxation. ${ }^{5}$

From the discussion above we formulate our second hypothesis as:

Hypothesis 2: Political Participation increases government spending.

\subsection{Measurement}

To empirically test our two hypotheses we need to find good indicators of the two dimensions of democracy we want to test. After exploring the many alternatives proposed by the literature, we settled on two that we believe effectively and accurately capture the two dimensions we are interested in.

\footnotetext{
${ }^{3}$ The Representation Theorem shows that the equilibrium platform can be characterized by optimizing a particular weighted sum of the enfranchised voters utilities (Coughlin and Nitzan 1981; Hettich and Winer 1999, chapter 4).

${ }^{4}$ See Norris (2001) or the discussion in Mueller and Stratmann (2003).

${ }^{5}$ This is, however, not inevitable. As shown by Aidt et al. (2008), an extension of the franchise can in some cases lead to retrenchment rather than to expansion.
} 
Competition Dummy We measure political competition using the Polity IV index developed by Marshall and Jaggers (2007). The Polity IV index has been used in recent studies as a general indicator of democracy or as a tool to classify political regimes (Avelino et al. 2005; Rodrik and Wacziarg 2004; Mulligan et al. 2004; Lopez-Cordova and Meissner 2008; Papaioannou and Siourounis 2008; and Persson 2005). However, Vanhanen (2000) noted that the Polity IV index is better suited as an indicator of political competition since none of the five underlying authority characteristics on which the Polity IV index is based are related to political participation as defined in this study and do not reflect suffrage reforms directly. The five underlying authority characteristics on which the Polity IV index is based are i) Competitiveness of executive recruitment: the extent that prevailing modes of advancement give subordinates equal opportunities to become superordinates; ii) Openness of executive recruitment: recruitment of the chief executive is "open" to the extent that all the politically active population has an opportunity, in principle, to attain the position through a regularized process; iii) Executive constraints: the extent of institutionalized constraints on the decision making powers of chief executives, whether individuals or collectivities; iv) Regulation of participation: the extent that there are binding rules on when, whether, and how political preferences are expressed; and v) Competitiveness of participation: the extent to which alternative preferences for policy and leadership can be pursued in the political arena. Notice that the first three characteristics relate to how easy it is to contest political power or to place constraints on the executive. The last two characteristics refer more specifically to "participation" and the regulation of elections.

Following a similar line of argument found in Vanhanen (2000), Aidt and Eterovic (2010) provide the example of Costa Rica to illustrate how the Index does not relay information regarding the extension of the franchise or actual election turnouts. Costa Rica presents a long history of successive, stable democratic regimes, which has been consistently scored by the Polity project as a 10---the highest possible ranking of a democratic system- since the 1900 s. And yet the Polity index does not take into account the voting restrictions on gender and class which were present throughout the first half of the century. While there may have been high levels of political competition, the exclusion of women (until 1949) and illiterates (until 1913) from voting in Costa Rica renders its score of 10 vacuous when it comes to understanding the real levels of political participation in the democratic process.

Consistent with the arguments presented above, we define a dummy variable -competition dummy -- that takes the value of 1 when the Polity IV index is positive and the value of 0 when the index is negative. ${ }^{6}$ This variable, therefore, measures the impact of political competition vis-a-vis a counterfactual of "restricted political competition".

Other potential measures of political competition such as the "win-margin" of the incumbent governor (Holbrook and Van Dunk 1993; Rogers and Rogers 2000) or the length of time a party has been in office (Skilling and Zeckhauser 2002) start from the

\footnotetext{
${ }^{6}$ We obtain essentially identical results if we entered the Polity IV index directly in the regression model.
} 
presumption that some basic democratic structures are in place, making them unsuitable for a study that covers episodes of autocracy as well as episodes of democracy. Furthermore, these variables are not always available for long periods of time and for a broad set of countries as is the case for the Polity IV index.

Participation Index We measure political participation by the participation index on the Vanhanen's Polyarchy database (Vanhanen 2000 and 2003a). The participation index is an aggregate of voter turnout in general elections and in referenda, in proportion to the total population. This index has been used in a number of studies to characterize political participation (Reiter and Tillman 2002; Fredriksson et al. 2005; and Davenport 2004). The index takes the value of 0 when there are no elections or referenda to participate in or when the Competition Dummy equals $0 .^{7,8}$

\subsection{Political Competition, Participation and the Size of Government around the World: Some Facts}

To test our two hypotheses, we have constructed an unbalanced panel data set covering 104 countries during the period 1960-2000. Many studies focus on a "world" sample that includes as many countries as possible (Mulligan et al. 2004; Boix 2003, chapter 5). This approach has the advantage of maximizing the cross country variation from which institutional effects can be identified. However, it puts together countries with very different economic and social conditions and histories making the homogeneity assumption required to justify a panel (or cross country) approach more restrictive. In this study we use a large set of control variables in order to decrease this problem. We also estimate separate regressions for each main geographical areas which are more likely to fulfill the homogeneity conditions to use a panel. An additional advantage of the approach we use is that the panel structure (as opposed to crosscountry analysis) allows us to reduce the risk of omitted variables bias.

We are interested in testing two hypotheses: that political competition reduces the size of the public sector, while political participation is associated with an expansion. To do this we use data on central government expenditure since data on general government spending is scarce and not available for a sufficiently long time period. We use public spending $(G / Y)$ measure d as a percentage of GDP $(Y)$ as an indicator of the size of (central) government.

Table 1 presents statistics on the size of government spending as percentage of GDP, the percentage of countries with high political competition and the average voters' turnout as percentage of the total population for our entire sample divided in decades and regions. A number of empirical facts emerge. First, the average central government spending as percentage of GDP has been increasing since the 1960s where it was around

\footnotetext{
${ }^{7}$ We set the participation index equal to zero when political competition is absent because it's not clear the meaning of electoral participation in an environment without political competition.

${ }^{8}$ See the Appendix for a precise definition of all the variables used in this study.
} 
$13 \%$ of the total GDP to more than $15 \%$ during the 1990 s. The average central government spending of the sample is $14 \%$ of the total GDP. As expected, Western Europe and North America are the regions with the largest governments, with an average central government spending of more than $18 \%$ of their total GDP. South Asia and Latin America are the regions with the smallest government, spending less than $11 \%$ of their total GDP. A second empirical fact we notice is regarding the trends of political participation and political competition around the world, which appear to be positively correlated. Both the level of political participation and political competition decreased during the 1970s and increased during the 1980s and 1990s. However, these movements are not homogeneous across regions. Comparing the 1960s with the 1990s, Eastern Europe and Central Asia saw the largest improvements in both political variables while the Middle East experienced the largest contraction. The average of our (dummy variable) politi cal competition is $53 \%$, which means that $53 \%$ of the time the countries in the sample are classified as having a competitive political system. The average political participation (in competitive elections) of the sample is $22 \%$ of the total population. Again, as expected, Western Europe and North America are by far the regions with the highest political competition and the highest political participation. The Middle East and Africa are the regions with the lowest political rights.

[Table1 to appear here]

Using a dichotomous definition of political competition and political participation, we can consider political arrangements or regimes along participatory and competitive dimensions. To do this, we define political competition as restricted if the Polity IV index is negative and unrestricted otherwise. We also define electoral participation as low if elections are competitive or less than $15 \%$ of the population participates in the selection of their government and high otherwise. Figure 1 presents the average government spending to GDP depending of the degree of both political competition and electoral participation. Interestingly, given a certain level of political participation, countries with high political competition tend to have smaller governments than countries with low competition. On the other hand, given the level of political competition, countries with high political participation tend to have larger governments than countries with lower degrees of political participation. This is consistent with the theoretical predictions we previously discussed; however, to get more robust insights, in the next section we turn to a proper regression analysis.

[Figure 1 to appear here] 


\subsection{The Econometric Specification}

We estimate the following panel model:

$$
y_{i, t}=\alpha_{i}+\eta_{t}+\beta_{1} x_{i, t}^{\text {competition }}+\beta_{2} x_{i, t}^{\text {participaiton }}+x_{i, t}^{\text {control }} \gamma+\varepsilon_{i, t}
$$

where $y_{i, t}$ is the public spending in country $i$ at time $t$ and $e_{i, t}$ is the error term with $\mathrm{E}\left(\mathrm{e}_{\mathrm{i}, \mathrm{t}}\right)=0$. The variable $\mathrm{x}_{\mathrm{i}, \mathrm{t}}^{\text {competition }}$ is the competition dummy and the variable $\mathrm{x}_{\mathrm{i}, \mathrm{t}}^{\text {participation }}$ is the participation index. Note that the competition dummy measures the impact of political competition vis-a-vis a counterfactual of "restricted political competition".

Since fiscal choices are affected by many other factors than political participation and competition, we include a vector $x_{i, t}^{\text {control }}$ of time-varying control variables to take some of these other factors into account. ${ }^{9}$ The control variables included in most regressions in the study are:

- Trade Openness: openness to international trade could be associated with larger government spending because a larger public sector reduces economic volatility and provides insurance (Rodrik 1998). We define trade openness as exports plus imports as a percentage of GDP.

- GDP per capita (in logarithms): this variable is included to control for the countries' levels of development.

- Growth: serves as a proxy for general development trends and business cycle effects.

- Urbanization Rate: measured as a proportion of the population who lives in urban areas. Urbanization is highly correlated with industrialization and economic and social progress -- factors which in themselves are likely to affect the tax structure and which through the processes discussed by Wagner (1883) should increase the need for public services and for regulation of economic activity.

- Population (in logarithms of the population in millions): this variable accounts for the possibility of increasing returns to scale in the provision of public goods.

- Income Equality: higher income inequality could put pressure on government spending and redistributionary policies. We use the percentage of the total area of cultivated land that is owned by family farmers (Vanhanen 2003b) as a proxy for income equality since measures such as the Gini-coefficient, are unavailable for most of the sample period.

- War: we include a dummy variable that takes the value 1 when there is an armed conflict in the territory.

\footnotetext{
${ }^{9}$ Precise definitions and the sources for each control variable are given in Appendix.
} 
- Inflation: this variable captures the fiscal implications of episodes of high inflation and could also be a proxy for economic crises.

- Federalism: the organization of a country into a federal state might have fiscal implications.

The model includes country fixed effects $\left(a_{i}\right)$ and year fixed effects $\left(?_{t}\right)$. Using this specification we rule out that the inference regarding the two parameters of interest $\left(\aleph_{1}\right.$ and $\beta_{2}$ ) is contaminated by unobserved determinants of fiscal choices that are constant over time (country fixed effects) or affect all countries at a given point in time in the same way (year fixed effects). Also, using the "within" variation to identify the impact of political participation and competition on fiscal choices (within a given country) over time, we attempt to reduces the risk of omitted variables bias. Therefore, the question we ask is if a given country increases its political participation (or competition), then, ceteris paribus, what would we expect the change in fiscal policy to be.

As suggested by Beck and Katz (1995), we estimate the model with a fixed effects estimator allowing for panel-specific standard errors and correlations between panel units. ${ }^{10}$ We have tested the stationarity of the data using the Fisher Test for panel unit roots and can in each case reject the null hypothesis that the series are non-stationary for all panel units. ${ }^{11}$ We additionally test the stationarity of the residuals of each of the regressions presented in the next section. In each case, we reject the null hypothesis that the series are non-stationary for all panel units. We focus in the long run relation between our institutional variables and fiscal outcomes; therefore we do not model dynamics explicitly. However, we correct for autocorrelation of order one and include a deterministic time trend in each regression.

\section{The Main Results}

The main results are reported in Table 2 . Regression 1 reports on a specification that does not include any of the time-varying control variables. Regre ssion 2 adds the full set of control variables we consider in this study. While regression 1 is likely to suffer from omitted variables bias, it has the virtue that it does not include potentially endogenous regressors on the right hand side. Regression 2, on the other hand, controls for the maximum range of time-varying observable factors. Both regressions provide strong support for our two hypotheses: that political competition reduces the size of government measured in terms of expenditure, while political participation increases the size of government. From Regression 2, a country that experiences an increase in political competition (from low to high) would see a fall in public expenditure of about 0.6 percentage points. In contrast, a country that experiences an increase in political participation from a situation with no participation to a situation in which 50 percent of

\footnotetext{
${ }^{10}$ The estimates are performed in Stata, version 10.

${ }^{11}$ The results of these and subsequent stationary tests are available upon request.
} 
the population participate in the selection of their government would see an increase in public expenditures of about 1.3 percentage points. Bearing in mind that, in our sample, the average spending as a percentage of GDP is around 15 per cent, these effects are substantial.

To check if our results are biased due to the violation of homogeneity restrictions, regressions 3 to 9 report the results for different geographical regions. ${ }^{12}$ The regressions for Eastern Europe-Central Asia and Latin America support our previous results. The Middle East and North Africa present a significant and negative effect of political competition on government spending while the region of East Asia Pacific presents a significant and positive effect of political participation on government spending. The estimation for Sub-Saharan Africa and South Asia are not significant for our political variables. Finally, Western Europe and North America present a positive and significant coefficient for the competition dummy. Regressions 10 and 11 focus on the areas where the results are not fully supportive of our main hypotheses. In particular, Regression 10 shows that taking together the areas of Middle East, North Africa, East Asia Pacific, SubSaharan Africa and South Asia we find negative, although non statically significant, effects of political competition on government spending and positive and statistically significant effects of political participation on government spending. In the case of Western Europe and North America, since the average percentage of countries in the region having high political competition is $94 \%$, our sample does not contain many periods where the political competition dummy equaled zero (low political competition). To account for this problem, in Regression 11 we run a similar specification to Regression 5 although using the Polity IV index (that scores from -10 to +10). After doing this, we obtain the expected signs for the political variables, although participation remains not significant.

Finally, Regression 12 test our main hypotheses using the other side of the government spending equation, this is, on government revenue as a percentage of GDP $(T / Y)$. Again, the results confirm our priors: political competition is negatively associated with government revenue and political participation is positively associated to government revenue.

[Table 2 to appear here]

While we focus on the effects of both political competition and political participation on the size of government, most of the existing empirical work focuses on one of these aspects in isolation. Many studies suggest the existence of a negative relationship between political competition and the size of government (Rogers and Rogers 2000; Skilling and Zeckhauser 2002; Ferris et al. 2008; Aidt and Jensen 2008a; Aidt et al. 2006).

\footnotetext{
${ }^{12}$ Table A1 in the appendix presents a list of the countries included in each geographical area.
} 
However, there are some studies that disagree. For example, Holbrook and Van Dunk (1993) show that political competition increases the size of US state government, through an increase in Medicare generosity and in disability protection.

Similarly, the literature on political participation and the size of government although more uniformly supportive of our findings, remains inconclusive. The extension of the voting franchise (with implies a major increase in voting participation) seems to lead to substantial increases in social spending and modest increases in total government spending (Husted and Kenny 1997). Higher electoral participation is associated with larger governments (Mueller and Stratmann 2003; Boix, 2001 and 2003, chapter 5). However, there exists evidence that points in the opposite direction (Aidt et al. 2006; Aidt and Jensen 2008b).

In conclusion, we believe our results add to the debate on the effects of political institutions on policy outcomes by including simultaneously both political competition and participation into the equation and providing evidence of the existence of different effects of these variables on government expenditure.

\subsection{The Effects of Compulsory Voting on Fiscal Outcomes}

An important albeit yet underdeveloped area of research is the effects of compulsory voting laws on fiscal outcomes. Empirical evidence supports the idea that compulsory voting strongly increases voting turnout (IDEA 1997; Liphart 1997). Our theoretical framework provides a simple mechanism in which compulsory voting might affect government spending. Through its direct effect on political participation compulsory voting laws are likely to have an indirect effect on government spending. When compulsory voting rules make citizens that would not vote voluntarily to participate at elections, it is modifying the demographic composition of the effective electorate. Since the poor and less educated fraction of the population is less likely to vote, the median voter under compulsory voting law is likely to be poorer than without the law and therefore, demand larger redistribution. Thus, we should observe compulsory voting rules to be associated to larger governments. However, not all compulsory voting laws are enforced to the same extent and therefore we expect the law to have different impact on political participation depending on its level of enforcement (O'Toole and Strobl 1995). IDEA (1997) provides a classification of compulsory voting regimes depending on its level of enforcement. Three types of regimes emerge: no enforcement regimes, weak enforcement regimes and strict enforcement regimes. ${ }^{13}$ of the 32 countries that have implemented compulsory voting regime at some point, 13 are Latin American countries, 10 are European, 4 are Asian and the rest from Africa and Australia. The average initial date for compulsory voting laws is 1944 . This is almost 20 years before the beginning date of our panel and therefore decreases our concerns of endogeneity between the enactment of compulsory voting laws and government

\footnotetext{
${ }^{13}$ Table A2 in the appendix presents a list of the countries that use or have used compulsory voting laws, their level of enforcement and the years the law its been in place.
} 
spending. To test the effects of compulsory voting laws on fiscal spending we create two sets of variables. The first set is a dummy variable that takes a value equal to one if the country has compulsory voting rules and zero if it does not. We call this variable Compulsory Voting. Subsequently, we take into account the possibility of differences in the level of enforcement creating three more dummy variables that take value one if the country has compulsory voting rules with no enforcement, weak enforcement and strict enforcement respectively, and zero if it does not. We call this variables No enforced Compulsory Voting, Weak Compulsory Voting and Strict Compulsory Voting.

In Table 3 we present a series of regressions with different specification in order to control for the effects of compulsory voting. The general picture that emerges from these regressions is that compulsory voting laws do not alter the main results of the paper. Political competition decreases government spending while participation increases it. However, compulsory voting laws seem to decrease the size of the overall effect of participation on government spending. Specifically, when compulsory voting laws are in place political participation has only half of the impact on government spending compared to the case where there are no compulsory voting laws in place (see Regression 13). Regressions 14 to 17 show that as the level of enforcement increases, compulsory voting laws have greater effect in reducing the positive impact of political participation on government spending.

Since enforced compulsory voting laws tend to increase the overall level of political participation, it is likely that their introduction had a positive effect on government spending. ${ }^{14}$ However, Regression 18 shows that as political participation increases, its marginal effect on government spending decreases.

[Table 3 to appear here]

\subsection{Robustness Checks}

We have undertaken a series of additional regressions to test the robustness of our main results. The details are available upon request. First, the choice of the estimation technique may have a major impact on the results. To judge if this is an issue of concern, we have tried several alternative econometric specifications. In particular, we have estimated the model i) without correcting for autocorrelation; ii) without including any control variables; iii) with country specific trends; and iv) with the Tobin technique. Our results remain robust to all these permutations.

\footnotetext{
${ }^{14}$ In our sample, the average political participation under compulsory voting rulesis $37 \%$ of the total population. On the other hand, participation absent of compulsory voting amounts to $31 \%$ of the total population.
} 
Second, the impact of changes in political institutions on the size of government may not be immediate. Fiscal lags are likely to be of some importance. We have run a set of regressions in which the two political variables have been lagged by 3 and 5 years, respectively. Table 4 indicates that our results are robust to fiscal lags of 3 years but for government spending become statistically insignificant at fiscal lags of 5 years although remain statistically significant for government revenue. Given the high regime volatility of some of the countries in our sample, a lack of significance using fiscal lags over 5 years would be hardly surprising.

The robustness checks carried out so far established that our results are robust to the removal of control variables, estimation techniques and fiscal lags of the political variables. However, the issue of endogeneity of our political variables and the fiscal outcomes remains. To deal with this issue we proceed to estimate our main regressions using instrumental variables technique.

[Table 4 to appear here]

\subsection{Instrumental Variables: System GMM}

We estimate a linear dynamic panel-data model including $\mathrm{p}$ lags of the dependent variable as covariates with unobserved panel-level effects. However, these unobserved panel-level effects could be correlated with the lagged dependent variables, therefore yielding inconsistent estimators. To deal with this issue, Arellano and Bond (1991), propose a GM M estimator which exploits all the linear moment restrictions, resting on the assumption of no serial correlation in the error term in an equation which contains individual effects, lagged dependent variable and no strictly exogenous variables. However, as pointed out by Arellano and Bover (1995), the main flaw of the original Arellano-Bond estimator is that lagged levels are poor instruments for first differences if the variables are close to a random walk. They further argue that if the original equation in levels is added to the system, additional instruments can be brought to increase efficiency. This version of the model, later on fully developed by Blundell and Bond (1998), is known as "System GM M " (Roodman 2009).

This estimator is designed for "small-T, large-N" panels that may contain fixed effects and separate from those fixed effects idiosyncratic errors that are heterokedastic and correlated within but not across individuals. To fulfill the first condition we collapse our panel in 5-year averages and perform our system estimation. We estimate a two-step robust "System GMM" regression using Windmeijer's (2005) correction for finite samples and report tests for autocorrelation, which is applied to the differenced residuals in order to purge the unobserved and perfectly autocorrelated residuals. In the case this condition is not fulfilled, it means that lags of the dependent variable (as well as instruments that are not strictly exogenous), are in fact endogenous and thus bad instruments. The results from the system GMM technique, presented in Table 5, are 
supportive to our main hypotheses. Political competition affects negatively fiscal expenditure and fiscal revenue. On the other hand, political participation positively affects our fiscal outcomes. Our political variables were treated as endogenous in all regressions. In Regressions 27 and 30, we additionally use our full set of control variables as strictly exogenous variables. We reject the null hypothesis of $A R(2)$ effects in all regressions. We further report the Hansen J statistic test of over-identifying restrictions to observe whether the instruments, as a group, are exogenous. ${ }^{15}$ The Hansen J statistic cannot reject the null hypothesis of joint exogeneity. This latter reinforces the validity of our results.

[Tables 5 to appear here]

\section{Conclusion}

Extending to a world sample the work done by Aidt and Eterovic (2010) for Latin American countries, we provide further empirical evidence of the importance of distinguishing between political competition and participation for the size of government. Our estimations strongly support the hypothesis that political participation and competition have opposite effects on the size of government. Higher levels of political competition tend to be associated to smaller governments. On the other hand, countries with higher levels of political participation tend to be associated to larger governments. Importantly, these findings are robust across geographical regions.

Controlling for the implementation and enforcement of compulsory voting laws does not affect our main results. However, as the level of enforcement increases, compulsory voting laws have greater effect in reducing the impact of political participation on government spending.

There are two potential problems with our estimations. First, our estimations could present endogeneity (political reforms might be driven by the same unobserved factors that determine fiscal choices). Second, our estimations could present reverse causality (that political reforms could be driven by fiscal considerations). ${ }^{16}$ The presence of any of these two problems would bias our estimate of the effect of political competition towards zero and would bias our estimate of the effect of political participation upward away from zero. To deal with these potential problems we have adopted a number of empirical strategies that minimize the likelihood of such biases:

\footnotetext{
${ }^{15}$ The Sargan test is not robust to heteroskedasticity and autocorrelations under the null hypothesis, while the Hansen J statistic is the minimized value of the two-step GM M criterion function, and therefore, robust.

${ }^{16}$ See, e.g., the discussion in Besley and Case (2000).
} 
1. In all our regressions, we control for country and year fixed effects and we also show that the results are robust to the inclusion of country specific trends. This rules out that our inference is contaminated by unobserved determinants that are constant over time (country fixed effects) or affect all countries at a given point in time in the same way (year fixed effects). We acknowledge that this reduces, but does not eliminate, the risk of omitted variables bias. In particular, omitted variables that vary over time within a country and which are correlated with our two political variables and the size of government pose a problem.

2. Compared to many other panel studies, we control for a relatively large number of both economic and demographic factors.

3. To address the problem of reverse causality, we have run, as discussed in Section 3, a set of regressions with our political variables lagged 3 and 5 years obtaining similar results to those reported in Table 2.

4. To deal with the problem of endogeneity, we estimate our main regression using instrumental variable techniques. Specifically, we estimate a two-step robust System GM M regression using Windmeijer's (2005) correction for finite samples and report tests for autocorrelation, which is applied to the differenced residuals in order to purge the unobserved and perfectly autocorrelated residuals.

Given the results of these checks, we find it unlikely that our results are spurious and caused by omitted variables or reverse causality.

Acknowledgments: We would like to thank Cassandra Sweet and Toke Aidt for helpful comments. The usual disclaimer applies.

\section{Appendix}

\section{List of variables}

- $\mathrm{G} / \mathrm{Y}$ is Consolidated Central Government Expenditures $(\mathrm{G})$ in percentage of GDP $(\mathrm{Y})$.

- $\mathrm{T} / \mathrm{Y}$ is Consolidated Central Government Revenues $(\mathrm{T})$ in percentage of GDP (Y).

- Competition dummy is a dummy variable that takes the value of 0 when the Polity IV index is equal or less than zero and takes a value of 1 when the Polity IV index is positive.

- Vanhanen's political competition index is defined as 100 minus the largest party's shares of votes (or seats). In the regressions, we use a dummy variable equal to 1 if the index is greater than 30 per cent. 
- Participation index is the voter turnout in each election as percentage of the total population. In case of indirect elections, only votes cast in the final election are taken into account. If electors have not been elected by citizens, only the number of actual electors is taken into account, which means that participation drops to 0 . If an election to choose electors has been held, participation is calculated from the number and distribution of votes in that election. National referendums increase the variable value by five percent and state (regional) referendums by one percent for the year they are held. Referendums can add to the degree of participation at most by 30 percent in a given year. Combined participation cannot be higher than 70 per cent, even in cases where the sum of participation and referendums would be higher than 70 per cent. Finally, we set the participation index equal to 0 when competition dummy equals 0 .

- GDP per capita is the logarithm of real GDP, PPP adjusted, divided by the total population of the country.

- Growth is the yearly growth rate of GDP per capita.

- Inflation is the percentage change in the consumer price index divided by 100.

- Income equality is proxied by family farms as a percentage of the total cultivated area or the total area of farm holdings.

- Population is the natural logarithm of the total population of the country.

- Urbanization rate is the percentage of the total population living in urban areas.

- Trade openness is exports plus imports as a percentage of GDP.

- War is a dummy variable that takes the value of 0 when there is no war or civil war and takes a value of 1 in the presence of a war or a civil war. In the sample, the dummy war takes the value 1 for Nicaragua from 1978 to 1989 (Sandinistas' revolution) and for El Salvador from 1982 to 1991 (civil war).

- Federalism is a dummy variable that takes the value of 1 when the country has a federal system in place and takes a value of 0 when the country has a federal system presidential system.

\section{Data sources}

Consolidated central government expenditures $(G / Y)$, consolidated central government revenues $(R / T)$ and the urbanization rate are from the World Development Indicators (WDI) 2009 World Bank, and the International Financial Statistics (IFS) from the International M onetary Fund (IMF). Political competition (Competition) is from the Polity IV Project, Political Regime Characteristics and Transitions, 1800-2007 (Monty G. $M$ arshall and Keith Jaggers). The participation index and our measure of income equality (family farm) are from Vanhanen (2003a,b), Democratization and power resources 18502000. Our measure of trade openness, GDP per capita (GDP) in levels and growth rates (Growth) and inflation rate (Inflation) are from Alan Heston, Robert Summers and 
Bettina Aten, Penn World Table Version 6.2, Center for International Comparisons of Production, Income and Prices at the University of Pennsylvania, September 2006. Our measure of federalism (Federalism) is from The Political Constraints Index (POLCON) (Witold Henisz, 2006). The war dummy (War) was constructed from Kreutz and Joakim 2010, forthcoming. "How and When Armed Conflicts End: Introducing the UCDP Conflict Termination Dataset," Journal of Peace Research.

\section{Construction of the data set}

For some control variables, there are gaps in the series. We have dealt with this by linear interpolation. The Polity IV index codes regimes transitions with -88, foreign interruption with -66 and periods of anarchy with -77 . In this case, we follow the suggestions given in the Polity IV user's manual (M arshall and Jaggers, 2007) and treat 66 as "system missing", - 77 are converted to a polity score of 0 and cases of transiti on (88) are pro-rated across the span of the transition.

[Table A1 to appear here]

[Table $\mathrm{A} 2$ to appear here]

\section{References}

Acemoglu, D., \& Robinson J. (2006). Economic origins of dictatorship and democracy. Cambridge: Cambridge University Press.

Aidt, T. (2003). Redistribution and the deadweight costs: The role of political competition. European Journal of Political Economy, 19, 205-226.

Aidt, T., Daunton, M ., \& Dutta, J. (2008). The Retrenchment hypothesis and the extension of the franchise in England and Wales. Economic Journal, 120, 990-1020.

Aidt, T., Dutta, J. \& Loukoianova, E. (2006). Democracy comes to Europe: Franchise extension and fiscal outcomes 1830-1938. European Economic Review, 50, 249-283.

Aidt, T. \& Eterovic, D. (2010). Political competition, participation and public finance in 20th Century Latin America. Forthcoming European Journal of Political Economy, also at Cambridge Working Papers in Economics 0714.

Aidt, T., \& Jensen, P. (2008a). Tax structure, size of government and the extension of the voting franchise in western Europe, 1860-1938. International Tax and Public Finance, 16, 362-394.

Aidt, T., \& Jensen, P. (2008b). The taxman tools up: An event history study of the introduction of the personal income tax. Journal of Public Economics, 93, 160-175. 
Arellano, M ., \& Bond, S. (1991). Some tests of specification for panel data: M onte Carlo evidence and an application to employment equations. Review of Economic Studies, 58, 277-97.

Arellano, M., \& Bover, O. (1995). Another look at the instrumental variable estimation of errorcomponents models. Journal of Econometrics, 68, 29-51.

Avelino, G., Brown, D., \& Hunter, W. (2005). The effects of capital mobility, trade openness, and democracy on social spending in Latin America, 1980--1999. American Journal of Political Science, $49,625-641$.

Beck, N., \& Katz, J. (1995). What to do (and not to do) with time-series cross-section data. American Political Science Review, 89, 634-647.

Becker, G. (1983). A theory among pressure groups for political influence. The Quarterly Journal of Economics, 98, 371-400.

Besley, T., \& Case, A. (2000). Unnatural experiments? Estimating the incidence of endogenous policies. The Economic Journal, 110, 672-694.

Blundell, R., \& Bond, S. (1998). Initial conditions and moment restrictions in dynamic panel data models. Journal of Econometrics, 87, 115-143.

Boix, C. (2001). Democracy, development, and the public sector. American Journal of Political Science, 45, 1-17.

Boix, C. (2003). Democracy and redistribution. Cambridge, UK: Cambridge University Press.

Buchanan, J., \& Wagner, R. (1977). Democracy in deficit: The political legacy of Lord Keynes. New York: Academic Press.

Chong, A.,\& Olivera, M. (2008). Does compulsory voting help equalize incomes? Economics and Politics, 20, 391-415.

Coughlin, P., \& Nitzan, S. (1981). Electoral outcomes with probabilistic voting and Nash social welfare maxima. Journal of Public Economics, 15, 113-132.

Dahl, R. (1971). Polyarchy: Participation and opposition. New Haven: Yale University Press.

Davenport, C., \& Armstrong, D. (2004). Democracy and the violation of human rights: A statistical analysis from 1976 to 1996. American Journal of Political Science, 48, 538-554.

Downs, A. (1957). An economic theory of democracy. New York: Harper and Row.

Ferejohn, J. (1986). Incumbent performance and electoral control. Public Choice, 50, 5-26.

Ferris, S., Park, S., \& Winer, S. (2008). Studying the role of political competition in the evolution of government size over long horizons. Public Choice, 137, 369-401.

Fredriksson, P., Neumayer, E., Damania, R., \& Gates, S. (2005). Environmentalism, democracy, and pollution control. Journal of Environmental Economics and M anagement, 49, 343 -365.

Hettich, W., \& Winer, S. (1988). Economic and political foundations of tax structure. American Economic Review, 78, 701-712.

Hettich, W., \& Winer, S. (1999). Democratic choice and taxation: A theoretical and empirical analysis. Cambridge: Cambridge University Press. 
Holbrook, T., \& Van Dunk, E. (1993). Electoral competition in the American states. American Political Science Review, 87, 955-62.

Husted, T., \& Kenny, L. (1997). The effect of the expansion of the voting franchise on the size and scope of government. Journal of Political Economy, 105, 54-82.

International Institute for Democracy and Electoral Assistance (IDEA) (1997). Voter turnout. Stockholm, Sweden: IDEA. http://www.idea.int/vt/index.cfm

Kenny, L., \& Winer, S. (2006). Taxation in the world: An empirical investigation of the importance of tax bases, collection costs and political regime. International Tax and Public Finance, 13, 181215.

Lindbeck, A., \& Weibull, J. (1987). Balanced budget redistribution as the outcome of political competition. Public Choice, 52, 273-297.

Liphart, A. (1997). Unequal participation: Democracy's unresolved dilemma. American Political Science Review, 91, 1-14.

Lopez-Cordova, E., \& M eissner, C. (2008). The globalization of trade and democracy, 1870-2000. World Politics, 60, 539-575.

M arshall, M ., Jaggers K. (2007). Polity IV project. Data set users manual. Center for International Development and Conflict Management, University of Maryland [www.bsos.umd.edu/cidcm/inscr/polity].

Mueller, D., \& Stratmann, T. (2003). The economic effects of democratic participation. Journal of Public Economics, 87, 2129-2155.

M ueller, D., \& M urrel, P. (1986). Interest groups and the size of the government. Public Choice, $48,125-145$.

Mulligan, C., Gil, R., \& Sala-i-M artin, X. (2004). Do democracies have different public policies than nondemocracies? Journal of Economic Perspective, 18, 51-74.

Norris, P. (2001). Digital Divide: Civic Engagement, Information Poverty, and the Internet Worldwide. Cambridge: Cambridge University Press.

Olson, M . (1965). The logic of collective action. Cambridge, M ass.: Harvard University Press.

Olson, M . (1982). The rise and decline of nations: Economic growth, stagflation, and social rigidities. New Haven: Yale University Press.

O'Toole, F., \& Strobl, E. (1995). Compulsory voting and government spending. Economics and Politics, 7, 271-280.

Papaioannou, E., \& Siourounis, G. (2008). Democratization and growth. Economic Journal, 118, 1520-1551.

Persson, T., Roland, G., \& Tabellini, G. (1997). Separation of powers and politi cal accountability. Quarterly Journal of Economics, 112, 1163-1202.

Persson, T., \& Tabellini, G. (2003). The economic effects of constitutions: What do the data say? Cambridge, M ass.: MIT Press. 
Persson, T., \& Tabellini, G. (2006). Democracy and development: The devil in the details. American Economic Review Papers and Proceedings, 96, 319-324.

Persson, T. (2005). Forms of democracy, policy and economic development. Unpublished Working Paper, International Economic Studies, Stockholm University.

Powell, G. (1982). Contemporary democracies. Cambridge, M ass.: Harvard University Press.

Przeworski, A., Alvarez, M., Cheibub, J., \& Limongi, F. (2000). Democracy and development: Political institutions and material well-being in the world, 1950-1990. Cambridge: Cambridge University Press.

Reiter, D., \& Tillman, E. (2002). Public, legislative, and executive constraints on the democratic initiation of conflict. The Journal of Politics, 64, 810-826.

Rodrik, D. (1998). Why do more open economies have bigger governments? Journal of Political Economy, 106, 997-1032.

Rodrik, D., \& Wacziarg, R. (2004). Do democratic transitions produce bad economic outcomes? American Economic Review, 95, 50-55.

Rogers, D., \& Rogers, J. (2000). Political competition and state government size: Do tighter elections produce looser budgets? Public Choice, 105, 1-21.

Roodman, D. (2009). How to do xtabond2: An introduction to difference and system GM M in Stata. Stata Journal, 9, 86-136.

Skilling, D., \& Zeckhauser, K. (2002). Political competition and debt trajectories in Japan and the OECD. Japan and the World Economy, 14, 121-35.

Tridimas, G., \& Winer, S. (2005). The political economy of government size. European Journal of Political Economy, 21, 643-666.

Vanhanen, T. (2000). A new dataset for measuring democracy. Journal of Peace Research, 37, 251-265.

Vanhanen, T. (2003a). Democratization: A comparative analysis of 170 countries. London: Routledge.

Vanhanen, T. (2003b). Democratization and power resources 1850-2000. University of Tampere. Department of Political Science and International Relations. Tampere : Finnish Social Science Data Archive.

Wagner, A. (1883). Three extracts on public finance. In R.A. M usgrave and A.T, Peacock (eds.), Classics in the Theory of Public Finance. London, Macmillan.

West, E., Winer, S. (1980). Optimal fiscal illusion and the size of government. Public Choice, 35, 607-622.

Windmeijer, F. (2005). A finite sample correction for the variance of linear efficient two-step GMM estimators. Journal of Econometrics, 126, 25-51. 
Table 1: Descriptive statistics.

\begin{tabular}{|c|c|c|c|c|c|c|c|}
\hline & Variable^ $^{\wedge}$ & \# of observations & Mean & & $\mathrm{Me}$ & an & \\
\hline & & & $1960-2000$ & $1960-1970$ & $1970-1980$ & 1980-1990 & $1990-2000$ \\
\hline Total Sample & $G / Y$ & 3860 & $14 \%$ & $13 \%$ & $14 \%$ & $15 \%$ & $15 \%$ \\
\hline $\begin{array}{l}\text { East Asia \& Pacific } \\
\text { Eastern Europe } \&\end{array}$ & $G / Y$ & 558 & $12 \%$ & $11 \%$ & $12 \%$ & $13 \%$ & $12 \%$ \\
\hline Central Asia & $G / Y$ & 413 & $16 \%$ & $9 \%$ & $11 \%$ & $12 \%$ & $18 \%$ \\
\hline $\begin{array}{l}\text { Latin America } \\
\text { M iddle East and }\end{array}$ & $G / Y$ & 848 & $11 \%$ & $10 \%$ & $12 \%$ & $13 \%$ & $12 \%$ \\
\hline $\begin{array}{l}\text { North Africa } \\
\text { Western Europe \& }\end{array}$ & $G / Y$ & 95 & $17 \%$ & $14 \%$ & $21 \%$ & $19 \%$ & $14 \%$ \\
\hline North America & $G / Y$ & 833 & $18 \%$ & $16 \%$ & $19 \%$ & $20 \%$ & $20 \%$ \\
\hline South Asia & $G / Y$ & 210 & $9 \%$ & $10 \%$ & $9 \%$ & $9 \%$ & $9 \%$ \\
\hline Sub-Saharan Africa & $G / Y$ & 903 & $15 \%$ & $14 \%$ & $16 \%$ & $16 \%$ & $15 \%$ \\
\hline Total Sample & Participation & 4443 & $22 \%$ & $17 \%$ & $16 \%$ & $21 \%$ & $31 \%$ \\
\hline $\begin{array}{l}\text { East Asia \& Pacific } \\
\text { Eastern Europe \& }\end{array}$ & Participation & 761 & $16 \%$ & $15 \%$ & $13 \%$ & $15 \%$ & $25 \%$ \\
\hline Central Asia & Participation & 493 & $18 \%$ & $5 \%$ & $4 \%$ & $5 \%$ & $30 \%$ \\
\hline $\begin{array}{l}\text { Latin America } \\
\text { Middle East and }\end{array}$ & Participation & 957 & $17 \%$ & $12 \%$ & $9 \%$ & $21 \%$ & $35 \%$ \\
\hline $\begin{array}{l}\text { North Africa } \\
\text { Western Europe \& }\end{array}$ & Participation & 134 & $5 \%$ & $8 \%$ & $5 \%$ & $0 \%$ & $3 \%$ \\
\hline North America & Participation & 929 & $51 \%$ & $46 \%$ & $49 \%$ & $55 \%$ & $55 \%$ \\
\hline South Asia & Participation & 284 & $15 \%$ & $12 \%$ & $14 \%$ & $12 \%$ & $25 \%$ \\
\hline Sub-Saharan Africa & Participation & 834 & $7 \%$ & $5 \%$ & $3 \%$ & $4 \%$ & $14 \%$ \\
\hline Total Sample & Competition & 4468 & $53 \%$ & $48 \%$ & $39 \%$ & $48 \%$ & $72 \%$ \\
\hline $\begin{array}{l}\text { East Asia \& Pacific } \\
\text { Eastern Europe \& }\end{array}$ & Competition & 767 & $42 \%$ & $41 \%$ & $32 \%$ & $36 \%$ & $61 \%$ \\
\hline Central Asia & Competition & 493 & $42 \%$ & $17 \%$ & $13 \%$ & $15 \%$ & $66 \%$ \\
\hline $\begin{array}{l}\text { Latin America } \\
\text { Middle East and }\end{array}$ & Competition & 957 & $55 \%$ & $45 \%$ & $29 \%$ & $63 \%$ & $98 \%$ \\
\hline $\begin{array}{l}\text { North Africa } \\
\text { Western Europe \& }\end{array}$ & Competition & 153 & $22 \%$ & $33 \%$ & $17 \%$ & $0 \%$ & $12 \%$ \\
\hline North America & Competition & 929 & $94 \%$ & $91 \%$ & $94 \%$ & $100 \%$ & $100 \%$ \\
\hline South Asia & Competition & 284 & $56 \%$ & $56 \%$ & $47 \%$ & $37 \%$ & $79 \%$ \\
\hline Sub-Saharan Africa & Competition & 834 & $31 \%$ & $29 \%$ & $18 \%$ & $20 \%$ & $50 \%$ \\
\hline
\end{tabular}

Source: See Appendix A1. ^ $\mathrm{G} / \mathrm{Y}$ is the consolidated central government expenditures in percentage of GDP, Participation is the participation index and Competition is the competition dummy.

Table Appendix A1 presents countries in each geographical area. 
Table 2: Political Competition, Participation and the Fiscal Expenditure.

\begin{tabular}{|c|c|c|c|c|c|c|}
\hline & $\begin{array}{c}(1) \\
\mathrm{G} / \mathrm{Y} \\
\text { All sample }\end{array}$ & $\begin{array}{c}(2) \\
\mathrm{G} / \mathrm{Y} \\
\text { All sample }\end{array}$ & $\begin{array}{c}\text { (3) } \\
\mathrm{G} / \mathrm{Y} \\
\text { Eastern Europe } \\
\text { and Central } \\
\text { Asia }\end{array}$ & $\begin{array}{c}\text { (4) } \\
\text { G/Y } \\
\text { South Asia }\end{array}$ & $\begin{array}{c}(5) \\
\text { G/Y } \\
\text { Western } \\
\text { Europe and } \\
\text { North } \\
\text { America }\end{array}$ & $\begin{array}{c}\text { (6) } \\
\mathrm{G} / \mathrm{Y} \\
\text { Latin } \\
\text { America }\end{array}$ \\
\hline $\begin{array}{l}\text { Competition } \\
\text { dummy }\end{array}$ & $\begin{array}{l}-0.014 \\
(0.001)^{* * *}\end{array}$ & $\begin{array}{l}-0.006 \\
(0.002)^{* * *}\end{array}$ & $\begin{array}{l}-0.054 \\
(0.011)^{* * *}\end{array}$ & $\begin{array}{l}0.002 \\
(0.007)\end{array}$ & $\begin{array}{l}0.006 \\
(0.003)^{*}\end{array}$ & $\begin{array}{l}-0.013 \\
(0.003)^{* * *}\end{array}$ \\
\hline Participation index & $\begin{array}{l}0.045 \\
(0.004)^{* * *}\end{array}$ & $\begin{array}{l}0.026 \\
(0.004)^{* * *}\end{array}$ & $\begin{array}{l}0.064 \\
(0.024) * * *\end{array}$ & $\begin{array}{l}0.015 \\
(0.023)\end{array}$ & $\begin{array}{l}-0.009 \\
(0.006)\end{array}$ & $\begin{array}{l}0.017 \\
(0.010) *\end{array}$ \\
\hline Trade Openness & & $\begin{array}{l}0.002 \\
(0.001)^{*}\end{array}$ & $\begin{array}{l}-0.105 \\
(0.019)^{* * *}\end{array}$ & $\begin{array}{l}0.080 \\
(0.008) * * *\end{array}$ & $\begin{array}{l}0.037 \\
(0.005)^{* * *}\end{array}$ & $\begin{array}{l}0.007 \\
(0.006)\end{array}$ \\
\hline GDP per capita & & $\begin{array}{l}0.011 \\
(0.002) * * *\end{array}$ & $\begin{array}{l}-0.115 \\
(0.016) * * *\end{array}$ & $\begin{array}{l}0.107 \\
(0.030) * * *\end{array}$ & $\begin{array}{l}-0.042 \\
(0.005) * * *\end{array}$ & $\begin{array}{l}-0.002 \\
(0.008)\end{array}$ \\
\hline Growth & & $\begin{array}{l}-0.061 \\
(0.016) * * *\end{array}$ & $\begin{array}{l}0.022 \\
(0.021)\end{array}$ & $\begin{array}{l}-0.051 \\
(0.031)\end{array}$ & $\begin{array}{l}-0.101 \\
(0.023)^{* * *}\end{array}$ & $\begin{array}{l}-0.024 \\
(0.021)\end{array}$ \\
\hline Income equality & & $\begin{array}{l}0.016 \\
(0.006) * * *\end{array}$ & $\begin{array}{l}-0.328 \\
(0.047)^{* * *}\end{array}$ & $\begin{array}{l}-0.073 \\
(0.038)^{*}\end{array}$ & $\begin{array}{l}0.119 \\
(0.009)^{* * *}\end{array}$ & $\begin{array}{l}-0.161 \\
(0.020)^{* * *}\end{array}$ \\
\hline Inflation & & -0.005 & -0.040 & -0.002 & -0.007 & 0.013 \\
\hline Population & & $\begin{array}{l}(0.003) \\
-0.046 \\
(0.004)^{* * *}\end{array}$ & $\begin{array}{l}(0.012)^{* * *} \\
0.181 \\
(0.062)^{* * *}\end{array}$ & $\begin{array}{l}(0.012) \\
0.108 \\
(0.052)^{* *}\end{array}$ & $\begin{array}{l}(0.011) \\
-0.024 \\
(0.016)\end{array}$ & $\begin{array}{l}(0.010) \\
0.032 \\
(0.014)^{* *}\end{array}$ \\
\hline Trend & & $\begin{array}{l}0.002 \\
(0.001) * * *\end{array}$ & $\begin{array}{l}0.014 \\
(0.002) * * *\end{array}$ & $\begin{array}{l}-0.007 \\
(0.002) * * *\end{array}$ & $\begin{array}{l}0.003 \\
(0.000) * * *\end{array}$ & $\begin{array}{l}0.001 \\
(0.000) * *\end{array}$ \\
\hline Federalism & & $\begin{array}{l}0.007 \\
(0.003)^{* *}\end{array}$ & $\begin{array}{l}0.000 \\
(0.000)\end{array}$ & $\begin{array}{l}0.000 \\
(0.000)\end{array}$ & $\begin{array}{l}0.082 \\
(0.060)\end{array}$ & $\begin{array}{l}0.005 \\
(0.008)\end{array}$ \\
\hline Urbanization rate & & $\begin{array}{l}-0.000 \\
(0.000)\end{array}$ & $\begin{array}{l}-0.003 \\
(0.002)^{*}\end{array}$ & $\begin{array}{l}-0.002 \\
(0.002)\end{array}$ & $\begin{array}{l}0.001 \\
(0.000)^{* * *}\end{array}$ & $\begin{array}{l}-0.002 \\
(0.000) * * *\end{array}$ \\
\hline War & & $\begin{array}{l}0.007 \\
(0.001)^{* * *}\end{array}$ & $\begin{array}{l}0.008 \\
(0.008)\end{array}$ & $\begin{array}{l}0.001 \\
(0.002)\end{array}$ & $\begin{array}{l}0.001 \\
(0.001)\end{array}$ & $\begin{array}{l}0.019 \\
(0.004) * * *\end{array}$ \\
\hline Observations & 3506 & 2706 & 108 & 145 & 684 & 704 \\
\hline \# of countries & 104 & 86 & 6 & 5 & 18 & 19 \\
\hline
\end{tabular}

Notes: Robust standard errors in parentheses; * significant at 10\%; ** significant at $5 \%$; *** significant at $1 \%$. All regressions include country and year fixed effects and we correct for autocorrelation of order 1. 
Table 2: Political Competition, Participation and the Fiscal Expenditure (continuation).

\begin{tabular}{|c|c|c|c|c|c|c|}
\hline & (7) & (8) & (9) & (10) & (11) & (12) \\
\hline & $G / Y$ & $G / Y$ & $G / Y$ & $G / Y$ & $G / Y$ & $R / Y$ \\
\hline & Middle & Sub- & East Asia & S. Asia, M iddle & Western & \\
\hline & East and & Saharan & Pacific & East, N. Africa, & Europe and & \\
\hline & North & & & Sub-Saharan & North & \\
\hline & Africa & & & $\begin{array}{l}\text { Africa and East } \\
\text { Asia Pacific }\end{array}$ & Americat & \\
\hline Competition & & & & -0.004 & -0.004 & \\
\hline dummy & -0.035 & -0.009 & -0.005 & & & -0.006 \\
\hline & $(0.013)^{* * *}$ & $(0.008)$ & $(0.005)$ & $(0.003)$ & $(0.002)^{* *}$ & $(0.002) * *$ \\
\hline Participation index & $\begin{array}{l}0.000 \\
(0000)\end{array}$ & 0.043 & $\begin{array}{l}0.027 \\
(0.0121 * *\end{array}$ & $\begin{array}{l}0.030 \\
(0.014) * *\end{array}$ & 0.006 & $\begin{array}{l}0.014 \\
(0007) * *\end{array}$ \\
\hline Trade openness & 0.008 & 0.003 & -0.010 & -0.000 & 0.036 & 0.018 \\
\hline & $(0.008)$ & $(0.003)$ & $(0.005)^{* *}$ & $(0.002)$ & $(0.004)^{* * *}$ & $(0.004)^{* * *}$ \\
\hline GDP per capita & -0.050 & 0.038 & 0.026 & 0.031 & -0.038 & 0.035 \\
\hline & $(0.024)^{* *}$ & $(0.013)^{* * *}$ & $(0.004)^{* * *}$ & $(0.004)^{* * *}$ & $(0.006)^{* * *}$ & $(0.003)^{* * *}$ \\
\hline Growth & -0.034 & -0.083 & -0.072 & -0.076 & -0.110 & -0.001 \\
\hline & $(0.021)$ & $(0.030) * * *$ & $(0.019) * * *$ & $(0.023) * * *$ & $(0.023) * * *$ & $(0.013)$ \\
\hline Income equality & -0.043 & 0.005 & 0.083 & 0.041 & 0.126 & -0.029 \\
\hline & $(0.035)$ & $(0.022)$ & $(0.013)^{* * *}$ & $(0.009) * * *$ & $(0.009) * * *$ & $(0.010) * * *$ \\
\hline Inflation & $\begin{array}{l}-0.009 \\
(0.004)^{* *}\end{array}$ & $\begin{array}{l}-0.026 \\
(0.007) * * *\end{array}$ & $\begin{array}{l}-0.013 \\
(0.009)\end{array}$ & $\begin{array}{l}-0.017 \\
(0.004)^{* * *}\end{array}$ & $\begin{array}{l}-0.007 \\
(0.011)\end{array}$ & $\begin{array}{l}-0.009 \\
(0.005) *\end{array}$ \\
\hline Population & $\begin{array}{l}-1.379 \\
(0.174)^{* * *}\end{array}$ & $\begin{array}{l}-0.029 \\
(0.030)\end{array}$ & $\begin{array}{l}-0.069 \\
(0.008)^{* * *}\end{array}$ & $\begin{array}{l}-0.006 \\
(0.014)\end{array}$ & $\begin{array}{l}-0.023 \\
(0.016)\end{array}$ & $\begin{array}{l}0.003 \\
(0.008)\end{array}$ \\
\hline Trend & $\begin{array}{l}0.053 \\
(0.008) * * *\end{array}$ & $\begin{array}{l}-0.000 \\
(0.001)\end{array}$ & $\begin{array}{l}0.001 \\
(0.000)^{*}\end{array}$ & $\begin{array}{l}-0.001 \\
(0.000)^{* * *}\end{array}$ & $\begin{array}{l}0.003 \\
(0.000) * * *\end{array}$ & $\begin{array}{l}-0.000 \\
(0.000)\end{array}$ \\
\hline Federalism & $\begin{array}{l}0.000 \\
(0.000)\end{array}$ & $\begin{array}{l}0.013 \\
(0.017)\end{array}$ & $\begin{array}{l}-0.245 \\
(0.032)^{* * *}\end{array}$ & $\begin{array}{l}0.034 \\
(0.012)^{* * *}\end{array}$ & $\begin{array}{l}0.079 \\
(0.060)\end{array}$ & $\begin{array}{l}0.008 \\
(0.014)\end{array}$ \\
\hline Urbanization rate & $\begin{array}{l}-0.007 \\
(0.001)^{* * *}\end{array}$ & $\begin{array}{l}-0.000 \\
(0.001)\end{array}$ & $\begin{array}{l}-0.002 \\
(0.000)^{* * *}\end{array}$ & $\begin{array}{l}-0.001 \\
(0.000)^{* * *}\end{array}$ & $\begin{array}{l}0.001 \\
(0.000)^{* * *}\end{array}$ & $\begin{array}{l}-0.001 \\
(0.000)^{* * *}\end{array}$ \\
\hline War & $\begin{array}{l}0.006 \\
(0.005)\end{array}$ & $\begin{array}{l}-0.004 \\
(0.003)\end{array}$ & $\begin{array}{l}0.010 \\
(0.002) * * *\end{array}$ & $\begin{array}{l}0.001 \\
(0.002)\end{array}$ & 0.002 & $\begin{array}{l}-0.002 \\
(0.002)\end{array}$ \\
\hline Observations & 81 & 590 & 394 & 1210 & 684 & 1921 \\
\hline \# of countries & 3 & 21 & 14 & 43 & 18 & 67 \\
\hline
\end{tabular}

Notes: Robust standard errors in parentheses; * significant at $10 \% ; * *$ significant at $5 \% ; * * *$ significant at $1 \%$. All regressions include country and year fixed effects and we correct for autocorrelation of order 1. + Regression uses polity IV divided by 10 instead of Competition Dummy. 
Table 3: Political Competition, Compulsory Voting and the Fiscal Expenditure.

\begin{tabular}{|c|c|c|c|c|c|c|}
\hline & (13) & (14) & (15) & (16) & (17) & (18) \\
\hline & $G / Y$ & $G / Y$ & $G / Y$ & $G / Y$ & $G / Y$ & $G / Y$ \\
\hline \multirow[t]{2}{*}{ Competition dummy } & -0.006 & -0.006 & -0.006 & -0.009 & -0.009 & -0.009 \\
\hline & $(0.001)^{* * *}$ & $(0.002) * * *$ & $(0.002) * * *$ & $(0.002) * * *$ & $(0.002) * * *$ & $(0.002)^{* * *}$ \\
\hline \multirow[t]{2}{*}{ Participation index } & & 0.030 & & & & 0.053 \\
\hline & & $(0.003)^{* * *}$ & & & & $(0.016)^{* * *}$ \\
\hline \multirow{2}{*}{$\begin{array}{l}\text { Participation } \\
\text { index*no } \\
\text { compulsory voting }\end{array}$} & 0.033 & & 0.032 & 0.057 & 0.057 & \\
\hline & $(0.004)^{* * *}$ & & $(0.004)^{* * *}$ & $(0.016)^{* * *}$ & $(0.016)^{* * *}$ & \\
\hline \multirow{2}{*}{$\begin{array}{l}\text { Participation } \\
\text { index*compulsory } \\
\text { voting }\end{array}$} & 0.017 & & & 0.041 & & \\
\hline & $(0.005)^{* * *}$ & & & $(0.017)^{* *}$ & & \\
\hline \multirow{2}{*}{$\begin{array}{l}\text { No enforcement } \\
\text { compulsory voting }\end{array}$} & & -0.018 & & & & \\
\hline & & $(0.002)^{* * *}$ & & & & \\
\hline \multirow{2}{*}{$\begin{array}{l}\text { Weak enforcement } \\
\text { compulsory voting }\end{array}$} & & -0.024 & & & & \\
\hline & & $(0.011)^{* *}$ & & & & \\
\hline \multirow{2}{*}{$\begin{array}{l}\text { Strict enforcement } \\
\text { compulsory voting }\end{array}$} & & -0.246 & & & & \\
\hline & & $(0.029) * * *$ & & & & \\
\hline \multirow{2}{*}{$\begin{array}{l}\text { Participation index* } \\
\text { no enforcement } \\
\text { compulsory voting }\end{array}$} & & & 0.012 & & 0.037 & \\
\hline & & & $(0.007)^{*}$ & & $(0.017)^{* *}$ & \\
\hline \multirow{2}{*}{$\begin{array}{l}\text { Participation index* } \\
\text { weak enforcement } \\
\text { compulsory voting }\end{array}$} & & & 0.020 & & 0.046 & \\
\hline & & & $(0.007) * * *$ & & $(0.018)^{* * *}$ & \\
\hline \multirow{2}{*}{$\begin{array}{l}\text { Participation index* } \\
\text { strict enforcement } \\
\text { compulsory voting }\end{array}$} & & & 0.015 & & 0.044 & \\
\hline & & & $(0.006)^{* *}$ & & $(0.017)^{* * *}$ & \\
\hline Participation index2 & & & & $\begin{array}{c}-0.036 \\
(0.021) *\end{array}$ & $\begin{array}{c}-0.039 \\
(0.021)^{*}\end{array}$ & $\begin{array}{c}-0.039 \\
(0.021)^{*}\end{array}$ \\
\hline Observations & 2706 & 2706 & 2706 & 2706 & 2706 & 2706 \\
\hline \# of countries & 86 & 86 & 86 & 86 & 86 & 86 \\
\hline
\end{tabular}

Notes: Robust standard errors in parentheses; * significant at $10 \%$; ** significant at $5 \%$; *** significant at $1 \%$. All regressions include country and year fixed effects and we correct for autocorrelation of order 1. 
Table 4: Robustness Checks. 3-year Lags and 5-year Lags on Political Variables.

\begin{tabular}{|c|c|c|c|c|}
\hline & (21) & (22) & (23) & (24) \\
\hline & $G / Y$ & $G / Y$ & $T / Y$ & $T / Y$ \\
\hline Competition (-3) & $\begin{array}{l}-0.006 \\
(0.001) * * *\end{array}$ & & $\begin{array}{l}-0.006 \\
(0.003)^{* *}\end{array}$ & \\
\hline Participation (-3) & $\begin{array}{l}0.013 \\
(0.003)^{* * *}\end{array}$ & & $\begin{array}{l}0.032 \\
(0.008)^{* * *}\end{array}$ & \\
\hline Competition (-5) & & $\begin{array}{l}0.000 \\
(0.001)\end{array}$ & & $\begin{array}{l}-0.010 \\
(0.003)^{* * *}\end{array}$ \\
\hline Participation (-5) & & $\begin{array}{l}-0.000 \\
(0.004)\end{array}$ & & $\begin{array}{l}0.050 \\
(0.007)^{* * *}\end{array}$ \\
\hline Trade Openness & $\begin{array}{l}0.003 \\
(0.001)^{* * *}\end{array}$ & $\begin{array}{l}0.007 \\
(0.003)^{* *}\end{array}$ & $\begin{array}{l}0.027 \\
(0.004)^{* * *}\end{array}$ & $\begin{array}{l}0.041 \\
(0.006)^{* * *}\end{array}$ \\
\hline GDP per Capita & $\begin{array}{l}0.009 \\
(0.002) * * *\end{array}$ & $\begin{array}{l}0.009 \\
(0.001)^{* * *}\end{array}$ & $\begin{array}{l}0.034 \\
(0.003)^{* * *}\end{array}$ & $\begin{array}{l}0.030 \\
(0.004)^{* * *}\end{array}$ \\
\hline Growth & $\begin{array}{l}-0.062 \\
(0.009)^{* * *}\end{array}$ & $\begin{array}{l}-0.063 \\
(0.009)^{* * *}\end{array}$ & $\begin{array}{l}0.003 \\
(0.013)\end{array}$ & $\begin{array}{l}0.002 \\
(0.013)\end{array}$ \\
\hline Income Equality & $\begin{array}{l}0.016 \\
(0.004)^{* * *}\end{array}$ & $\begin{array}{l}0.018 \\
(0.005)^{* * *}\end{array}$ & $\begin{array}{l}0.000 \\
(0.011)\end{array}$ & $\begin{array}{l}0.008 \\
(0.010)\end{array}$ \\
\hline Inflation & $\begin{array}{l}-0.005 \\
(0.002) * *\end{array}$ & $\begin{array}{l}-0.005 \\
(0.002) * *\end{array}$ & $\begin{array}{l}-0.011 \\
(0.006)^{* *}\end{array}$ & $\begin{array}{l}-0.011 \\
(0.005)^{* *}\end{array}$ \\
\hline Population & $\begin{array}{l}-0.049 \\
(0.004)^{* * *}\end{array}$ & $\begin{array}{l}-0.051 \\
(0.003)^{* * *}\end{array}$ & $\begin{array}{l}0.009 \\
(0.007)\end{array}$ & $\begin{array}{l}0.014 \\
(0.007)^{*}\end{array}$ \\
\hline Trend & $\begin{array}{l}0.002 \\
(0.001)^{* * *}\end{array}$ & $\begin{array}{l}0.002 \\
(0.001)^{* * *}\end{array}$ & $\begin{array}{l}-0.001 \\
(0.000)^{* *}\end{array}$ & $\begin{array}{l}-0.001 \\
(0.000)^{* *}\end{array}$ \\
\hline Federalism & $\begin{array}{l}0.009 \\
(0.003) * * *\end{array}$ & $\begin{array}{l}0.012 \\
(0.003) * * *\end{array}$ & $\begin{array}{l}0.007 \\
(0.014)\end{array}$ & $\begin{array}{l}0.005 \\
(0.013)\end{array}$ \\
\hline Urbanization rate & $\begin{array}{l}-0.000 \\
(0.000)\end{array}$ & $\begin{array}{l}-0.000 \\
(0.000)\end{array}$ & $\begin{array}{l}-0.001 \\
(0.000)^{* * *}\end{array}$ & $\begin{array}{l}-0.001 \\
(0.000)^{* * *}\end{array}$ \\
\hline War & $\begin{array}{l}0.006 \\
(0.001) * * *\end{array}$ & $\begin{array}{l}0.006 \\
(0.001)^{* * *}\end{array}$ & $\begin{array}{l}-0.002 \\
(0.002)\end{array}$ & $\begin{array}{l}-0.001 \\
(0.002)\end{array}$ \\
\hline $\begin{array}{l}\text { Observations } \\
\# \text { of countries }\end{array}$ & $\begin{array}{l}2697 \\
86\end{array}$ & $\begin{array}{l}2686 \\
86\end{array}$ & $\begin{array}{l}1849 \\
64\end{array}$ & $\begin{array}{l}1841 \\
64\end{array}$ \\
\hline
\end{tabular}


Table 5: Political Competition, Participation and the Fiscal Outcomes - System GM M estimations.

\begin{tabular}{|c|c|c|c|c|c|c|}
\hline \multirow{4}{*}{ Competition dummy } & (25) & (26) & (27) & (28) & (29) & (30) \\
\hline & $\mathrm{G} / \mathrm{Y} \dagger$ & $\mathrm{G} / \mathrm{Y} \dagger$ & $G / Y \ddagger$ & $\mathrm{T} / \mathrm{Y} \dagger$ & $\mathrm{T} / \mathrm{Y} \dagger$ & $T / Y \ddagger$ \\
\hline & -0.053 & -0.049 & -0.039 & -0.052 & -0.023 & -0.029 \\
\hline & $(0.013)^{* * *}$ & $(0.021)^{* *}$ & $(0.012) * * *$ & $(0.014)^{* * *}$ & $(0.023)$ & $(0.016)^{*}$ \\
\hline \multirow[t]{2}{*}{ Participation index } & 0.145 & 0.031 & 0.062 & 0.116 & 0.067 & 0.072 \\
\hline & $(0.024) * * *$ & $(0.054)$ & $(0.037) *$ & $(0.027)^{* * *}$ & $(0.067)$ & $(0.041)^{*}$ \\
\hline \multirow[t]{2}{*}{ Trade openness } & & -0.005 & 0.001 & & 0.085 & 0.023 \\
\hline & & $(0.009)$ & $(0.015)$ & & $(0.022)^{* * *}$ & $(0.007)^{* * *}$ \\
\hline \multirow[t]{2}{*}{ GDP per capita } & & 0.015 & 0.008 & & -0.001 & 0.004 \\
\hline & & $(0.011)$ & $(0.006)$ & & $(0.013)$ & $(0.004)$ \\
\hline \multirow[t]{2}{*}{ Growth } & & -0.120 & -0.117 & & 0.689 & 0.328 \\
\hline & & $(0.125)$ & $(0.086)$ & & $(0.193)^{* * *}$ & $(0.078)^{* * *}$ \\
\hline Income equality & & $\begin{array}{c}0.064 \\
(0.036) *\end{array}$ & $\begin{array}{l}0.025 \\
(0.021)\end{array}$ & & $\begin{array}{c}0.001 \\
(0.047)\end{array}$ & $\begin{array}{c}0.005 \\
(0.020)\end{array}$ \\
\hline \multirow[t]{2}{*}{ Inflation } & & -0.024 & 0.030 & & -0.202 & -0.022 \\
\hline & & $(0.048)$ & $(0.026)$ & & $(0.070) * * *$ & $(0.025)$ \\
\hline \multirow[t]{2}{*}{ Population } & & -0.014 & -0.009 & & 0.004 & 0.000 \\
\hline & & $(0.010)$ & $(0.004)^{* *}$ & & $(0.016)$ & $(0.003)$ \\
\hline \multirow[t]{2}{*}{ Federalism } & & -0.006 & 0.009 & & -0.053 & -0.031 \\
\hline & & $(0.083)$ & (0.019) & & $(0.033)$ & $(0.011)^{* * *}$ \\
\hline Urbanization rate & & $\begin{array}{c}0.001 \\
(0.001)\end{array}$ & $\begin{array}{c}0.000 \\
(0.000)\end{array}$ & & $\begin{array}{c}0.001 \\
(0.001)\end{array}$ & $\begin{array}{c}0.001 \\
(0.000) *\end{array}$ \\
\hline \multirow[t]{2}{*}{ War } & & -0.018 & 0.009 & & -0.011 & 0.007 \\
\hline & & $(0.032)$ & $(0.013)$ & & $(0.024)$ & $(0.017)$ \\
\hline Observations & 542 & 522 & 440 & 483 & 409 & 409 \\
\hline \# of countries & 94 & 94 & 86 & 67 & 66 & 66 \\
\hline \# of Instruments & 70 & 70 & 73 & 67 & 61 & 69 \\
\hline Hansen test ( $p$-value) & 0.196 & 0.229 & 0.233 & 0.430 & 0.352 & 0.560 \\
\hline AR 1 test (p-value) & 0.003 & 0.006 & 0.006 & 0.065 & 0.036 & 0.077 \\
\hline AR 2 test ( $p$-value) & 0.975 & 0.162 & 0.262 & 0.258 & 0.842 & 0.482 \\
\hline
\end{tabular}

Notes: System-GM M estimations for dynamic panel-data models. Sample period: 1960-2000.

$\dagger$ Political variables were treated as endogenous. Their lagged values two periods were used as instruments in the first difference equations and their once lagged first-differences were used in the levels equations.

₹ Political variables were treated as endogenous. Non-political variables were treated as strictly exogenous variables. Their lagged values two periods were used as instruments in the first difference equations and their once lagged first-differences were used in the levels equations.

Two-step results using robust standard errors corrected for finite samples (using Winmeijer's, 2005, correction).

t-statistics are in parenthesis. Significance level at which the null hypothesis is rejected: ***, $1 \% ; 5 \%$, and *, $10 \%$. 
Table A1: Countries included in each Geographical Region.

\begin{tabular}{|c|c|c|c|c|c|c|}
\hline $\begin{array}{l}\text { Sub-Saharan } \\
\text { Africa }\end{array}$ & $\begin{array}{l}\text { East Asia \& } \\
\text { Pacific }\end{array}$ & $\begin{array}{l}\text { Eastern Europe \& } \\
\text { Central Asia }\end{array}$ & $\begin{array}{l}\text { Latin } \\
\text { America }\end{array}$ & $\begin{array}{l}\text { Middle } \\
\text { East and } \\
\text { North } \\
\text { Africa }\end{array}$ & $\begin{array}{l}\text { Western } \\
\text { Europe \& } \\
\text { North } \\
\text { America }\end{array}$ & South Asia \\
\hline Benin & Australia & Albania & Argentina & Iran & Austria & Afghanistan \\
\hline Botswana & Cambodia & Armenia & Bolivia & Lebanon & Belgium & Bangladesh \\
\hline Burkina Faso & China & Azerbaijan & Brazil & Syria & Canada & India \\
\hline African Republic & Hong Kong & Belarus & Chile & & Denmark & Nepal \\
\hline Congo & Indonesia & Bosnia & Colombia & & Finland & Pakistan \\
\hline Côte d'Ivoire & Japan & Bulgaria & Costa Rica & & France & Sri Lanka \\
\hline Equatorial Guinea & Laos & Croatia & Dominican $\mathrm{F}$ & epublic & Germany & \\
\hline Ghana & Malaysia & Czech Republic & Ecuador & & Greece & \\
\hline Kenya & Mongolia & Estonia & El Salvador & & Ireland & \\
\hline Lesotho & New Zealand & Georgia & Guatemala & & Israel & \\
\hline Madagascar & North Korea & Hungary & Honduras & & Italy & \\
\hline Malawi & Philippines & Kazakhstan & M exico & & Netherlands & \\
\hline Mali & Singapore & Kyrgyzstan & Nicaragua & & Norway & \\
\hline Mauritius & South Korea & Latvia & Panama & & Portugal & \\
\hline Niger & Taiwan & Lithuania & Paraguay & & Spain & \\
\hline Nigeria & Thailand & Macedonia & Peru & & Sweden & \\
\hline Sao Tome & Vietnam & Moldova & Trinidad & & Switzerland & \\
\hline Senegal & & Poland & Uruguay & & UK & \\
\hline South Africa & & Romania & Venezuela & & US & \\
\hline Sudan & & Russia & & & & \\
\hline Uganda & & Serbia/M ontenegro & & & & \\
\hline \multirow[t]{7}{*}{ Zambia } & & Slovakia & & & & \\
\hline & & Slovenia & & & & \\
\hline & & Tajikistan & & & & \\
\hline & & Turkey & & & & \\
\hline & & Turkmenistan & & & & \\
\hline & & Ukraine & & & & \\
\hline & & Uzbekistan & & & & \\
\hline
\end{tabular}


Table A2: Compulsory voting around the world.

\begin{tabular}{|c|c|c|}
\hline Country & Level of enforcement+ & Year introduced \\
\hline Argentina & Weak & 1912 \\
\hline Australia $^{\mathrm{b}}$ & Weak & 1924 \\
\hline Austria & Weak & $\mathrm{N} / \mathrm{A}$ \\
\hline Belgium & Strict & 1893 \\
\hline Bolivia & $\mathrm{N} / \mathrm{A}$ & 1952 \\
\hline Brazil & Weak & $\mathrm{N} / \mathrm{A}$ \\
\hline Chile & Weak & 1925 \\
\hline Costa Rica & No & $\mathrm{N} / \mathrm{A}$ \\
\hline Cyprus & Strict & 1960 \\
\hline Dominican Rep & No & $\mathrm{N} / \mathrm{A}$ \\
\hline Ecuador & Weak & 1936 \\
\hline Egypt & $\mathrm{N} / \mathrm{A}$ & 1956 \\
\hline Fiji & Strict & 1996 \\
\hline France & $\mathrm{N} / \mathrm{A}$ & $1950 \mathrm{~s}$ or $1960 \mathrm{~s}$ \\
\hline Gabon & $\mathrm{N} / \mathrm{A}$ & $\mathrm{N} / \mathrm{A}$ \\
\hline Greece & Weak & $\mathrm{N} / \mathrm{A}$ \\
\hline Guatemala & No & $\mathrm{N} / \mathrm{A}$ \\
\hline Honduras & No & $\mathrm{N} / \mathrm{A}$ \\
\hline Italy & Weak & $\mathrm{N} / \mathrm{A}$ \\
\hline Liechtenstein & Weak & $\mathrm{N} / \mathrm{A}$ \\
\hline Luxembourg & Strict & $\mathrm{N} / \mathrm{A}$ \\
\hline Mexico & Weak & $\mathrm{N} / \mathrm{A}$ \\
\hline Nauru & Strict & 1965 \\
\hline Netherlands & No & 1917 to 1967 \\
\hline Paraguay & $\mathrm{N} / \mathrm{A}$ & $\mathrm{N} / \mathrm{A}$ \\
\hline Peru & Weak & 1933 \\
\hline Philippines & No & $1972-1986$ \\
\hline Singapore & Strict & $\mathrm{N} / \mathrm{A}$ \\
\hline Switzerland $^{\mathrm{C}}$ & Weak & 1974 \\
\hline Thailand & No & $\mathrm{N} / \mathrm{A}$ \\
\hline Turkey & Weak & $\mathrm{N} / \mathrm{A}$ \\
\hline Uruguay & Strict & 1934 \\
\hline Average initial date & & 1944 \\
\hline
\end{tabular}

Sources: Chong and Olivera (2008) from IDEA (1997).

Notes: +No enforcement happens in countries where mandatory laws are not complemented with sanctions. Weak enforcement corresponds to countries where, for example, limited budgets do not allow governments to place enforcement as a high priority. Strict or strong enforcement countries enforce the law with a high priority. Sanctions vary from a simple explanation for not voting to fines, possible imprisonment, and infringements of civil rights or disenfranchisement. N/A, not available. ${ }^{b}$ W hile IDEA classifies Australia as strict, we saw the need to reclassify the country as weak in order to keep consistency with the classification of other countries (e.g. Peru). 'Switzerland has mixed enforcement; it is strict in one canton only (Schaffhaus en) but weak in the rest. 
Figure 1: Size of government and the Classification of political regimes in two dimensions: competition and participation.

\begin{tabular}{|c|c|}
\hline $\begin{array}{c}\text { high political competition, } \\
\text { low political participation }\end{array}$ & $\begin{array}{r}\text { high political competition, } \\
\text { high political participation }\end{array}$ \\
$\mathbf{G} / \mathbf{Y}=12 \%=15.0 \%$
\end{tabular}

